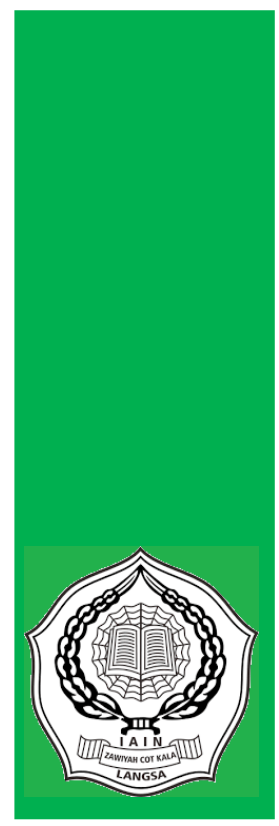

\title{
PENGARUH RELIGIUSITAS, KUALITAS PELAYANAN, KUALITAS PRODUK TERHADAP LOYALITAS NASABAH TABUNGAN PADA PT. BANK ACEH SYARIAH KANTOR CABANG PEMBANTU DARUSSALAM
}

\author{
Arif Munandar ${ }^{1}$, Nurma Sari $^{2}$ \\ Universitas Syiah Kuala ${ }^{2}$ Universitas Syiah Kuala \\ 1)Ariefmunandar.s96@gmail.com
}

\begin{abstract}
The purpose of research is to know the influence of religiality, quality of service, quality of products to customer loyalty savings at PT. Bank. Aceh Branch Helper Darussalam. Sample of this research as much as 100 customers using the formula Slovin with a sample technique is purposive sampling. The type of research used in this study is quantitative. The data used is the primary data obtained by using questionnaires. The results of this study showed that religiusity, quality of service, the product quality is the simultaneous effect on customer loyalty savings at PT. Bank. Aceb Branch maid Darussalam. A partial factor of religiusity and quality of service, the culinary products to give positive and significant impact on customer loyalty at PT. Bank. Aceh, but one of the variables (product culitas) has a level of Lower influence than the variable religiusisity and quality of service.
\end{abstract}

Keywords : Islamic Banking, Religiosity, Service of Quality, Product of Quality, loyalty.

\section{PENDAHULUAN}

Lembaga perbankan memiliki tiga fungsi utama, yaitu menerima simpanan uang, menyalurkan uang, dan memberikan pelayanan pengiriman uang. Di dalam sejarah perekonomian umat islam, pembiayaan yang dilakukan dengan akad yang sesuai dengan syariah telah menjadi bagian dari umat Islam sejak zaman Rasulullah SAW.

Amir menjelaskan diskusi Bank Syariah sebagai pilar ekonomi Islam mulai dilakukan Pada tahun 1970-an usaha-usaha untuk mendirikan bank islam mulai menyebar ke banyak Negara seperti Pakistan, Iran, dan sudan, bahkan 
$102 \sim$ Pengaruh Religiusitas, Kualitas Pelayanan,

Kualitas Produk Terhadap Loyalitas Nasabah

Tabungan Pada PT. Bank Aceh Syariah

Kantor Cabang Pembantu Darussalam

mengubah seluruh sistem keuangan di Negara itu menjadi sistem nir-bunga sehingga semua lembaga keuangan di Negara tersebut beroperasi tanpa menggunakan bunga ${ }^{1}$. Perkembangan perbankan syariah sangat berpengaruh bagi penduduk Indonesia yang masyarakatnya mayoritas muslim. Prinsip Perbankan Syariah berdasarkan UU No 10 Tahun 1998 diantaranya adalah prinsip bagi hasil (mudharabah), prinsip kerjasama (musharakah), prinsip jual beli (murabahah), prinsip sewa (ijarah), atau dengan adanya peralihan kepemilikan dari pihak bank oleh pihak lain (ijarah wa iqtina).

Bank Aceh merupakan Bank lokal pertama di Aceh yang kepemilikan dominannya adalahPemerintah Aceh. ${ }^{2}$ Pada tanggal 7 September 1957, Dewan Pemerintah Aceh menyetujui pendirian bank daerah dengan Surat Keputusan Nomor 7/DPRD/5. Menunjuk Notaris Pangihutan Tomboenan, wakil notaries di Kutaraja untuk mendirikan PT yang bernama "Bank Kesejahteraan Atjeh, NV" dengan modal dasar Rp25.000.000,-. Pada tanggal 2 February 1960, Menteri Keuangan mengeluarkan izin dengan surat keputusan No. 12096/BUM/II, Menteri Kehakiman mengeluarkan surat pengesahan dalam Bentuk

\footnotetext{
${ }^{1}$ Amir, Machmud, Bank Syariah kebijakan dan Studi Empiris di Indonesia, (Jakarta: Erlangga, 2010.). h.19.

${ }^{2}$ Farlian, Talbani dkk Meretas Reaksi Jalan Panjang Bank Aceh Konversi Syariah. (Jurnal Perspektif Ekonomi Darussalam,2017 Volume 3 Nomor 1, Maret), h.44.
}

Hukum dengan surat keputusan No. J.A.5/22/ 9 tanggal 18 Maret 1960. Berdasarkan Keputusan Dewan Komisioner Otoritas Jasa Keuangan (OJK) Nomor. KEP-44/D.03/2016 tanggal 19 september 2016 perihal pemberian izin perubahan kegiatan Usaha perbankan Konvensional menjadi perbankan Syariah. Tentu hal tersebut akan berpengaruh terhadap nasabah yang menempatkan sejumlah dananya di Bank Aceh Syariah saat ini. Maka pihak Bank Aceh khususnya PT. Bank Aceh Syariah kantor Cabang pembantu Darussalam memerlukan sejumlah perencanan dan strategi dalam upaya menjaga loyalitas nasabahnya. Berdasarkan data jumlah nasabah pembiayaan dan dana pihak ketiga yang terdapat di Bank Aceh syariah capem Darussalam dijelaskan pada tabel 1.1 
Tabel 1.1

PT.Bank Aceh Syariah Kantor Capem Darussalam Jumlah Nasabah Pembiayaan Dan Dana Pihak Ketiga

\begin{tabular}{|r|l|r|r|r|r|}
\hline \multirow{2}{*}{ NO } & \multirow{2}{*}{ Keterangan } & \multicolumn{5}{|c|}{ Tahun } \\
\cline { 3 - 6 } & & \multicolumn{1}{|c|}{$\mathbf{2 0 1 5}$} & \multicolumn{1}{|c|}{$\mathbf{2 0 1 6}$} & \multicolumn{1}{c|}{$\mathbf{2 0 1 7}$} & \multicolumn{1}{c|}{ Sep2018 } \\
\hline 1 & Pembiayaan & 1.208 & 1.073 & 1.007 & 980 \\
\hline 2 & Giro & 597 & 615 & 621 & 656 \\
\hline 3 & Tabungan & 10.245 & 10.049 & 10.379 & 10.909 \\
\hline 4 & Deposito & 113 & 119 & 113 & 137 \\
\hline \multicolumn{2}{|c|}{ Jumlah } & $\mathbf{1 2 . 1 6 3}$ & $\mathbf{1 1 . 8 5 6}$ & $\mathbf{1 2 . 1 2 0}$ & $\mathbf{1 2 . 6 8 2}$ \\
\hline
\end{tabular}

Sumber: PT.Bank Aceh Syariah Capem Darussalam (2018). Data diolah 
$104 \sim$ Pengaruh Religiusitas, Kualitas Pelayanan,

Kualitas Produk Terhadap Loyalitas Nasabah

Tabungan Pada PT. Bank Aceh Syariah

Kantor Cabang Pembantu Darussalam

Sebuah perusahaan menjadi

besar dan bonafit tidak hanya dipengaruhi oleh variabel kesehatan keuangan CAMELS, namun terdapat beberapa faktor lain yang mempengaruhi semakin berkembangnya sebuah perusahaan. Dalam hal ini peneliti melihat dari sisi yang berbeda yakni religuitas, kualitas pelayanan, kualitas produk berpengaruh terhadap loyalitas nasabah tabungan pada salah satu bank di Aceh yaitu Bank Aceh Syariah. Semakin loyal nasabah menggunakan jasa layanan Bank Aceh maka akan semakin memajukan bank tersebut kedepannya, mengingat perbankan merupakan salah satu lembaga yang menitikberatkan pelayanan sebagai produk jasa. Religiusitas adalah hubungan pribadi dengan Ilahi Yang Maha Kuasa, Maha Pengasih dan Maha Penyayang (Tuhan) yang berkonsekuensi hasrat untuk berkenan kepada pribadi yang Ilahi itu dengan melaksanakan kehendak-Nya dan menjauhi yang tidak dikehendaki-Nya (larangan-Nya) ${ }^{3}$. Kualitas pelayanan menjadi faktor penentu dalam menari minat pelanggan maupun nasabah, sebagaimana dikemukan oleh Aliansyah kualitas pelayanan berfokus pada upaya pemenuhan kebutuhan dan keinginan pelanggan, serta ketepatan penyampaiannya untuk mengimbangi harapan pelanggan ${ }^{4}$

\footnotetext{
${ }^{3}$ Suhardiyanto, Pendidikan Religiusitas, (Jogjakarta: Kanisius, 2001),h.48

${ }^{4}$ Aliansyah, Teuku., dkk, Pengaruh Dimensi Kualitas Pelayanan Terhadap Kepuasan Nasabah Bank Aceh Syariah Cabang
}

Adapun faktor ketiga kualitas produk adalah suatu bentuk dengan nilai kepuasan yang kompleks, nasabah membeli jasa perbankan untuk menyelesaikan masalah dan nasabah memberikan nilai dalam proporsi terhadap kemampuan layanan untuk melakukan hal tersebut, nilai yang diberikan nasabah berhubungan dengan benefit atau keuntungan yang akan diterimanya. ${ }^{5}$ Hasan menyatakan loyalitas merupakan kesetiaan nasabah terhadap suatu ukuran kedekatan nasabah pada sebuah merek/produk, termasuk kemungkinan memperbaharui kontrak merek/produk di masa yang akan datang, loyalitas nasabah menjadi kunci sukses, tidak hanya dalam jangka pendek, tetapi keunggulan bersaing yang berkelanjutan karena loyalitas nasabah memiliki nilai strategik bagi perusahaan. $^{6}$

Penelitian ini merupakan penelitian kuantitatif dengan menggunakan regresi linier berganda sebagai model analisis. Data bersifat primer dan skunder yang penulis peroleh dilapangan baik bersumber kuisioner maupun laporan-laporan

Banda Aceh, ( Jurnal Manajemen Pasca Sarjana Universitas Syiah Kuala, November 2012, Vol.1 No.1) h.32

${ }^{5}$ Rachmat Hidayat, Pengaruh Kualitas Layanan, Kualitas Produk Dan Nilai Nasabah Terhadap Kepuasan Dan Loyalitas Nasabah Bank Mandiri. (Jurnal Manajemen Dan Kewirausahaan,2009) Vol.11, No. 1, Maret: h.59.

${ }^{6}$ Ali Hasan, Marketing Bank Syariah. (Bogor: Ghalia Indonesia,2010), h.103. 
publikasi. Penulisan ini terdiri dari lima bahagian, dimana diawali dengan pendahuluan dilanjutkan dengan landasan teori, pada bagian ketiga yaitu metodologi yang berisikan model yang digunakan dalam penulisan, selanjutnya bahagian empat berisi hasil penelitian yang diakhiri oleh penutup pada bagian terakhir.

\section{TINJAUAN TEORITIS}

\section{Religiusitas}

Religiusitas diartikan sebagai seberapa jauh pengetahuan, seberapa kokoh keyakinan, seberapa pelaksanaan ibadah dan kaidah dan seberapa dalam penghayatan atas agama yang dianutnya. Bagi seorang Muslim, religiusitas dapat diketahui dari seberapa jauh pengetahuan, keyakinan, pelaksanaan dan penghayatan atas agama Islam. ${ }^{7}$

\section{Indikator Pengukuran Religusitas terhadap Loyalitas Nasabah}

Ancok dan Suroso menyebutkan bahwa religiusitas dibagi menjadi 5 indikator yang sangat penting yaitu: ${ }^{8}$

1. Keyakinan (ideologis)

2. Praktik agama (Ritualistik)

3. Pengalaman (eksperensial)

4. Pengetahuan (intelektual)

${ }^{7}$ Fuad, Nashori dan Rachmy Diana Mucharam, Mengembangkan Kreativitas dalam Perspektif Psikologi Islam.(Yogyakarta : Menara Kudus, 2002), h.70.

${ }^{8}$ Ancok, D. \& Suroso, F. N, Psikologi Islami Solusi Islam Atas ProblemProblem Psikologi. (Yogayakarta: Pustaka Pelajar, 2008), h.80.

\section{Pengamalan (konsekuensial)}

\section{Kualitas Pelayanan}

Kualitas dan pelayanan
nasabah yang superior secara
konsisten akan memungkinkan
perusahaan membangun sejumlah
kekuatan penting seperti rintangan
yang masuk pesaing, loyalitas nasabah,
produk yang terbedakan, biaya
pemasaran yang lebih rendah, dan
harga yang lebih tinggi. Pelayanan
adalah setiap tindakan atau kegiatan
yang dapat ditawarkan oleh suatu
pihak kepada pihak lain, yang pada
dasarnya tidak berwujud dan tidak
mengakibatkan kepemilikan apapun. ${ }^{10}$

\section{Indikator Faktor Pelayanan Terhadap Loyalitas Nasabah}

$$
\text { Lupiyoadi }
$$

menyebutkanbahwakualitaspelayanand ibagimenjadi 5 Indikatoryaitu :

1. Berwujud (Tangible)

2. Kehandalan (Reliability)

3. Ketanggapan (Responsiveness)

4. Empati (Emphaty)

5. Jaminan (Assurance)

\section{Kualitas Produk}

Kualitas Produk dapat mempengaruhi persepsi dan kepuasan nasabah melalui ketepatan waktu pelayanan penyampaian, ketersediaan produk, kebenaran janji promosi atas

\footnotetext{
${ }^{9}$ Toni Wijaya, Manajemen Kualitas Jasa. (Jakarta barat: PT. Indeks,2011), h.24.

${ }^{10}$ Kotler, Philip \& Gary Amstron, Manajemen Pemasaran di Indonesia: Analisis, Perencanaan, Implementasidan Pengendalian, (Jakarta : Salemba Empat,2002),h.84.
} 
$106 \sim$ Pengaruh Religiusitas, Kualitas Pelayanan,

Kualitas Produk Terhadap Loyalitas Nasabah

Tabungan Pada PT. Bank Aceh Syariah

Kantor Cabang Pembantu Darussalam

produk dan layanan, kesesuaian produk, keamanan dan keselamatan, fleksibiltas dalam pembayaran, dan kemudahan pengambilan, serta kemampuan penyempurnaan produk layanan secara terus-menurus tanpa batas. ${ }^{11}$

\section{Indikator Pengukuran Faktor Kualitas Produk Terhadap Loyalitas Nasabah}

Lupiyoadi mengemukakan bahwa kualitas suatu produk memiliki delapan dimensi pengukuran yang terdiri dari aspek-aspek berikut: ${ }^{12}$

1. Kinerja (Performance)

2. Keragamanproduk (Features)

3. Kehandalan (Reliability)

4. Kesesuaian (Conformance)

5. Dayatahan/ketahanan (Durabil

\section{Loyalitas Nasabah}

Loyalitas nasabah mencerminkan loyalty nasabah pada merek tertenru. Loyalitas pelanggan sebagai pola pikir pelanggan memegang sikap yang menguntungkan perusahaan dengan berkomitmen untuk membeli produk/ layanan kembali dan merekomendasikan pada siapa yang di kenalnya.$^{13} \quad$ Loyalitas merupakan

11 Ali Hasan, Marketing Bank Syariah. (Bogor: Ghalia Indonesia, 2010), h. 88 .

$\begin{array}{rr}{ }^{12} \text { Rambat Lupiyoadi, } & \text { Manajemen } \\ \text { Pemasaran Jasa. } & \text { (Jakarta: }\end{array}$ empat,2001).

${ }^{13}$ Saravana kumar, Effect of service quality on customer loyalty: Emperical komitmen yang dipegang kuat untuk membeli lagi suatu produk atau jasa tertentu di masa depan.James F Engel menemukan dua alasan penting mempertahankan loyalitas pelanggam, diantaranya: 1) umumnya lebih mudah mempertahankan pelanggan yang sudah ada dari pada menarik baru; 2) Kehilangan pelanggan dapat menjadi bencana bagi perusahaan. ${ }^{14}$
Devidance from co-operative bank. Int.J.Bus. Adm Res, Rev. 2, 87-94

${ }^{14}$ James Engel et al, Prilaku Konsumen Jilid 2 (Jakarta:Binarupa Aksara.1994) 
Karakteristik konsumen loyal terhasap suatu produk memiliki beberapa karakter, antara lain ${ }^{15}$ :

1. Konsumen yang loyal cendrung lebih percaya diri

2. Konsumen yang lebih loyal cendrung mengurangi resiko dengan pembelian berulang pada merek yang sama

3. Konsumen yang loyal lebih mengarah pada kesetiaan terhadap suatu toko

4. Kelompok konsumen minor cenderung untuk lebih loyal.

Menurut Kartajaya Hermawan karakteristik loyalitas nasabah dapat didasari pada perilaku pembeli, diantaranya:

1. Melakukan pembelian berulang (repeat purchase)

2. Membeli anatar lini prodeuk dan jasa (purchase across product lines)

3. Mereferensikan kepada orang lain (referrals)

4. Mrnunjukkan kekebalan tarikan dari para pesaing ${\text { (retention })^{16}}^{16}$

Nasabah yang loyal merupakan aset yang sangat berharga yang perlu senantiasa dipelihara oleh perbankan. Kita ketahui bahwa bank merupakan

15 Assael, Consumer Behavior and Marketing Action.(Boston Massachusset,AS: Kent Published Company,2002) edisi3.

${ }^{16}$ Hermawan Kartajaya, Boosting Loyalty Marketing Performance,(Jakarta :Markplus Inc dan Bandung: Mizan Pustaka, 2007), $h .4$ lembaga jasa yang bergerak di bidang keuangan. Oleh karena nya sudah menjadi kewajiban bank memberikan pelayanan yang sangat baik bagi para nasabah. Dengan adanya produk serta layanan prima menjadikan nasabah berpikir ulang untuk melakukan change pada lembaga keuangan lainnya.

Menjaga loyalitas nasabah dengan memberikan layanan prima bukanlah suatu hal yang asing dalam Islam. Islam sebagai agama yang universal dalam ajarannya selalu mengedepankan nilai-nilai maqasyid syariah. Nilai ini sejalan dengan maksud agar tercapainya kesejahteraan, tidak akan loyal seseorang kepada sesuatu jika ia tidak merasakan kenyamanan, keamanan yang berujung pada kesejahteraan.

\section{Kerangka Pemikiran}

Menurut Ismail loyalias nasabah dapat terwujud dengan adanya prediktor layanan yang baik, Adzan Noor Bakri mengemukakan nilai-nilai religuitas mempengaruhi tingkat loyalitas nasabah Bank Syariah. Menurutnya nasabah yang loyal akan sangat berdampak pada keuntungan suatu perusahaan dalam hal ini perbankan Syariah. Adapun kerangka pemikiran yang dapat dikembangkan terlihat pada gambar berikut. 
$108 \sim$ Pengaruh Religiusitas, Kualitas Pelayanan,

Kualitas Produk Terhadap Loyalitas Nasabah

Tabungan Pada PT. Bank Aceh Syariah

Kantor Cabang Pembantu Darussalam

Gambar1.1

Skema Konsep Penelitian

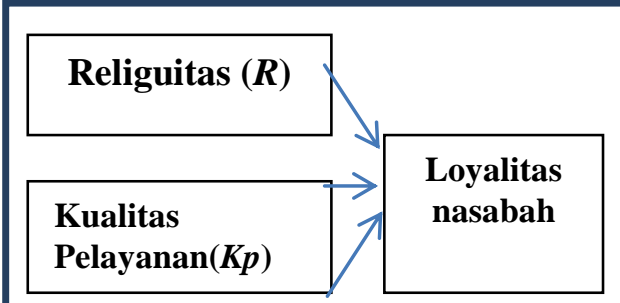

Kualitas Produk

(D) 


\section{METODE PENELITIAN}

Penelitian ini dilakukan Pada

PT. Bank Aceh Syariah Kantor Cabang Pembantu Darussalam. Sedangkan objek yang diteliti adalah Nasabah aktif pada PT. Bank Aceh Syariah Kantor Cabang Pembantu Darussalam.

\section{Populasi dan sampel}

Sampel pada penelitian ini adalah Nasabah Bank Aceh Cabang pembantu Darussalam. Penelitian ini menggunakan 100 sampel dengan metode purposive sampling (sampel bersyarat) syaratnya yaitu: nasabah
Bank Aceh Syariah Cabang pembantu Darussalam, sudah menggunakan tabungan di Bank Aceh Syariah cabang pembantu Darussalam $\geq 1$ tahun.

\section{Operasional Variabel Penelitian}

Variabel independen dalam penelitian ini adalah Religiusitas yang dilambangkan dengan (R), Kualitas Pelayanan yang dilambangkan dengan (Kp), Kualitas Produk yang dilambangkan dengan (P). Dan variabel dependennya adalah Loyalitas yang dilambangkan dengan (L).

Tabel 1.2

Operasional variabel

\begin{tabular}{|c|c|c|c|c|}
\hline No & JenisVariabel & Definisi & Indikator & Skala \\
\hline 1. & Religiusitas (R) & $\begin{array}{l}\text { Religiusitas adalah } \\
\text { keberagamaan, yaitu } \\
\text { suatu keadaan yang ada } \\
\text { dalam diri seseorang } \\
\text { yang mendorongnya } \\
\text { untuk bertingkah laku } \\
\text { sesuai dengan kadar } \\
\text { ketaatannya kepada } \\
\text { agama (jalaludin } \\
\text { 88:2003). }\end{array}$ & $\begin{array}{l}\text { 1. Keyakinan } \\
\text { 2. Praktik agama } \\
\text { 3. Pengalaman } \\
\text { 4. Pengetahuan } \\
\text { 5. Pengamalan }\end{array}$ & $\begin{array}{c}\text { Interval } \\
(1-5)\end{array}$ \\
\hline 2. & $\begin{array}{l}\text { Kualitas } \\
\text { Pelayanan (Kp) }\end{array}$ & $\begin{array}{l}\text { Menurut Tjiptono (2002: } \\
\text { 58) menyebutkan bahwa } \\
\text { kualitas pelayanan } \\
\text { merupakan tingkatan } \\
\text { kondisi baik-buruknya } \\
\text { sajian yang diberikan } \\
\text { perusahaan jasa dalam } \\
\text { hal memuaskan } \\
\text { nasabah,. }\end{array}$ & $\begin{array}{l}\text { 1. Berwujud } \\
\text { 2. Kehandalan } \\
\text { 3. Ketanggapan } \\
\text { 4. Empati } \\
\text { 5. Jaminan }\end{array}$ & $\begin{array}{c}\text { Interval (1- } \\
5)\end{array}$ \\
\hline 3. & Kualitas & Menurut Tjiptono (1997) & 1. Kinerja & \\
\hline
\end{tabular}


$110 \sim$ Pengaruh Religiusitas, Kualitas Pelayanan,

Kualitas Produk Terhadap Loyalitas Nasabah

Tabungan Pada PT. Bank Aceh Syariah

Kantor Cabang Pembantu Darussalam

\begin{tabular}{|c|c|c|c|c|}
\hline & Produk (P) & $\begin{array}{l}\text { bahwa Produk yang } \\
\text { ditawarkan dapat } \\
\text { meliputi barang fisik, } \\
\text { jasa, orang atau pribadi, } \\
\text { tempat, organisasi, dan } \\
\text { ide. yang berupa manfaat } \\
\text { tangiblemaupun intangible } \\
\text { yang dapat memuaskan } \\
\text { pelanggan. }\end{array}$ & $\begin{array}{l}\text { 2. Keragaman } \\
\text { produk } \\
\text { 3. Kehandalan } \\
\text { 4. Kesesuaian } \\
\text { 5. Dayatahan/ } \\
\text { ketahanan }\end{array}$ & \\
\hline 4. & $\begin{array}{l}\text { Loyalitas } \\
\text { Nasabah (L) }\end{array}$ & $\begin{array}{l}\text { Loyalitas adalah mereka } \\
\text { yang sangat puas dengan } \\
\text { produk tertentu sehingga } \\
\text { mempunyai antusiasme } \\
\text { untuk memperkenalkan } \\
\text { kepada siapa pun yang } \\
\text { mereka kenal, Nuraini } \\
(2009) \text {. }\end{array}$ & $\begin{array}{l}\text { 1. Pembeli } \\
\text { 2. Rekomendasi } \\
\text { 3. Pilihantetap } \\
\text { 4. Word of mouth } \\
\text { (Wahyu, } \\
\text { 2015) }\end{array}$ & $\begin{array}{c}\text { Interval } \\
(1-5)\end{array}$ \\
\hline
\end{tabular}




\section{Teknik Analisis Data}

$\begin{array}{llr} & \text { Penelitian ini merupakan } \\ \text { penelitian kuntitatif yaitu untuk } & \\ \text { menguji pengaruh Religiusitas, }\end{array}$ Kualitas Pelayanan, Kualitas Produk Terhadap Loyalitas Nasabah Tabungan Pada PT. Bank Aceh Syariah Kantor Cabang Pembantu Darussalam. Sehingga penelitian ini menggunakan regresi linear berganda Berikut bentuk persamaan umumnya:

$$
\mathbf{L}=\mathbf{a}+\beta 1 \mathrm{R}+\beta 2 \mathrm{Kp}+\beta 3 \mathbf{P}+
$$

e

Dimana (L) sebagai Loyalitas Nasabah, $a$ (alpha) merupakan konstanta, $\beta \mathrm{R}, \beta K \phi, \beta P$ sebagai koefisien regresi, sehingga $(\mathrm{R})$ Religiusitas $(\mathrm{Kp})$ Kualitas Pelayan (P) kualitas produk dan (e) error.

\section{HASIL DAN PEMBAHASAN}

\section{Karakteristik Responden}

Karakteristik responden dalam penelitian ini merupakan data-data mengenai responden yang merupakan Nasabah PT. Bank Aceh Syariah Kantor Cabang Pembantu Darussalam, yang dapat dilihat dari jenis kelamin, usia, pendidikan formal, pekerjaan.

Tabel 1.3

Karakteristik Responden Berdasarkan Jenis Kelamin

\begin{tabular}{|c|c|c|}
\hline $\begin{array}{c}\text { JenisKe } \\
\text { lamin }\end{array}$ & $\begin{array}{c}\text { Frek } \\
\text { uensi }\end{array}$ & $\begin{array}{c}\text { Perse } \\
\text { ntase }\end{array}$ \\
\hline Laki- & 45 & 45 \\
\hline
\end{tabular}

\begin{tabular}{|l|c|c|}
\hline laki & & \\
\hline $\begin{array}{l}\text { Peremp } \\
\text { uan }\end{array}$ & 55 & 55 \\
\hline Total & $\mathbf{1 0 0}$ & $\mathbf{1 0 0}$ \\
\hline
\end{tabular}

Sumber: Hasil penelitian (Mei, 2019) diolah

Berdasarkan Tabel 1.3 dapat dilihat bahwa dari 100 responden yang diteliti, responden berjenis kelamin laki-laki lebih sedikit yaitu 45 nasabah dan 55 responden yang berjenis kelamin perempuan yaitu lebih banyak di banding laki-laki.

Tabel 1.4

Karakteristik Responden

Berdasarkan Usia

\begin{tabular}{|c|c|c|}
\hline Usia & Frekuensi & Persentase \\
\hline$<21$ & 11 & 11 \\
\hline $21-30$ & 21 & 21 \\
\hline $31-40$ & 23 & 23 \\
\hline $41-50$ & 17 & 17 \\
\hline $51-60$ & 16 & 16 \\
\hline$>60$ & 12 & 12 \\
\hline Total & $\mathbf{1 0 0}$ & $\mathbf{1 0 0}$ \\
\hline
\end{tabular}

Sumber: Hasil penelitian (Mei, 2019)

diolah

Berdasarkan Tabel 1.4 . tersebut dapat dilihat bahwa dari 100 responden tedapat nasabah yang berusia $31 \mathrm{~s} / \mathrm{d} \quad 40$ lebih sering berinteraksi dalam menggunakan jasa perbankan dibuktikan dengan jumlah responden sebanyak 23 nasabah.

Tabel 1.5

Karakteristik Responden Berdasarkan Pendidikan Formal 
$112 \sim$ Pengaruh Religiusitas, Kualitas Pelayanan,

Kualitas Produk Terhadap Loyalitas Nasabah

Tabungan Pada PT. Bank Aceh Syariah

Kantor Cabang Pembantu Darussalam

\begin{tabular}{|l|c|c|}
\hline \multicolumn{1}{|c|}{ Pendidikan } & Frekuensi & Persentase \\
\hline SMP & 3 & 3 \\
\hline SMA & 21 & 21 \\
\hline Diploma & 10 & 10 \\
\hline S1 & 45 & 45 \\
\hline S2 & 14 & 14 \\
\hline S3 & 7 & 7 \\
\hline Total & $\mathbf{1 0 0}$ & $\mathbf{1 0 0}$ \\
\hline
\end{tabular}

Sumber: Hasil penelitian (Mei, 2019) diolah

BerdasarkanTabel 1.5. dapat dilihat tamatS1 lebih dominan dalam bahwa dari 100 responden yang menggunakan jasa bank Aceh Syariah dipilihterdapat45 nasabah yang kcp darussalam

Tabel 1.6

Karakteristik Responden Berdasarkan Pekerjaan

\begin{tabular}{|l|c|c|}
\hline \multicolumn{1}{|c|}{ Profesi/pekerjaan } & Frekuensi & Persentase \\
\hline Guru/Dosen & 37 & 37 \\
\hline POLRI/TNI & 0 & 0 \\
\hline Pegawai Kantor & 9 & 9 \\
\hline Dokter & 5 & 5 \\
\hline Perawat/Bidan & 8 & 8 \\
\hline Camat/Sekcam & 1 & 1 \\
\hline Sekda/StafAhli & 2 & 2 \\
\hline Mahasiswa & 22 & 22 \\
\hline Lainnya & 16 & 16 \\
\hline Total & $\mathbf{1 0 0}$ & $\mathbf{1 0 0}$ \\
\hline
\end{tabular}

Sumber: Hasil penelitian (Mei, 2019) diolah

Berdasarkan Tabel 1.6. dapat dilihat bahwa dari 100 responden yang terbanyak yaitu yang berprofesi sebagai Guru/Dosen sebanyak 37 nasabah.

\section{Hasil Pengujian Instrumen Penelitian}

Kualitas data yang diperoleh dari pengujian instrument penelitian dapat dievaluasi melalui uji validitas dan uji reliabilitas yang digunakan dalam penelitian ilmu-ilmu sosial. 


\section{Uji Validitas}

Pengujian validitas yang digunakan dalam penelitian ini adalah validitas item, yaitu untuk mengetahui apakah item-item dari pertanyaan yang ditanyakan dalam kuesioner penelitian valid atau tidak. Suatu instrumen yang valid atau sah mempunyai validitas yang tinggi, sebaliknya instrumen yang kurang valid berarti memiliki validitas yang rendah. Pengujian validitas data dalam penelitian ini dilakukan secara statistik, yaitu menggunakan uji dengan bantuan SPSS.

Tabel 1.7

Hasil Uji Validitas

\begin{tabular}{|c|c|c|c|c|}
\hline Variabel & $\begin{array}{c}\text { Nomor } \\
\text { Item }\end{array}$ & Nilair $_{\text {hitung }}$ & Nilair $_{\text {tabel }}$ & Keterangan \\
\hline \multirow{5}{*}{$\begin{array}{l}\text { Religiusitas } \\
\text { (R) }\end{array}$} & A1.1 & 0,609 & 0,196 & Valid \\
\hline & A1.2 & 0,718 & 0,196 & Valid \\
\hline & A1.3 & 0,605 & 0,196 & Valid \\
\hline & A1.4 & 0,677 & 0,196 & Valid \\
\hline & A1.5 & 0,675 & 0,196 & Valid \\
\hline \multirow{5}{*}{$\begin{array}{c}\text { KualitasPelayanan } \\
\text { (Kp) }\end{array}$} & B2.1 & 0,632 & 0,196 & Valid \\
\hline & B2.2 & 0,649 & 0,196 & Valid \\
\hline & B2.3 & 0,646 & 0,196 & Valid \\
\hline & B2.4 & 0,653 & 0,196 & Valid \\
\hline & B2.5 & 0,597 & 0,196 & Valid \\
\hline \multirow{5}{*}{$\begin{array}{l}\text { KualitasProduk } \\
\text { (P) }\end{array}$} & $\bar{C} 3.1$ & 0,689 & 0,196 & Valid \\
\hline & C3.2 & 0,616 & 0,196 & Valid \\
\hline & C3.3 & 0,732 & 0,196 & Valid \\
\hline & C3.4 & 0,774 & 0,196 & Valid \\
\hline & C3.5 & 0,634 & 0,196 & Valid \\
\hline \multirow{4}{*}{$\begin{array}{l}\text { Loyalitas } \\
\text { (L) }\end{array}$} & D4.1 & 0,632 & 0,196 & Valid \\
\hline & D4.2 & 0,798 & 0,196 & Valid \\
\hline & D4.3 & 0,757 & 0,196 & Valid \\
\hline & D4.4 & 0,725 & 0,196 & Valid \\
\hline
\end{tabular}

Sumber: Hasil penelitian (Mei, 2019) diolah

Berdasarkan Tabel 1.7 tersebut dapat disimpulkan bahwa semua item pertanyaan variabel Religiusitas (R), Kualitas Pelayanan (Kp), Kualitas Produk (P) adalah valid. Karena $r_{\text {hitung }}$ $>r_{\text {tabel }}(0,196)$ dengan demikian, layak digunakan untuk melakukan penelitian selanjutnya. 
$114 \sim$ Pengaruh Religiusitas, Kualitas Pelayanan,

Kualitas Produk Terhadap Loyalitas Nasabah

Tabungan Pada PT. Bank Aceh Syariah

Kantor Cabang Pembantu Darussalam

\section{Uji Reliabilitas}

Koefisien alpha yang dapat diterima $>0,60$, apabila Croncbach Alpha< 0,60 berarti tidak reliabel, apabila besarnya Cronbach's Alpha lebih besar dari 0,60 maka instrument dalam penelitian tersebut handal. Berikut ini adalah hasil uji reliabilitas dengan menggunakan program aplikasi SPSS :

Tabel 1.8

Hasil Uji Reliabilitas

\begin{tabular}{|l|c|c|}
\hline \multicolumn{1}{|c|}{ Variabel } & $\begin{array}{c}\text { Cronba } \\
\text { ch's } \\
\text { Alpha }\end{array}$ & $\begin{array}{c}\text { Keteran } \\
\text { gan }\end{array}$ \\
\hline Religiusitas & 0,669 & Reliabel \\
\hline $\begin{array}{l}\text { KualitasPela } \\
\text { yanan }\end{array}$ & 0,631 & Reliabel \\
\hline $\begin{array}{l}\text { KualitasProd } \\
\text { uk }\end{array}$ & 0,723 & Reliabel \\
\hline Loyalitas & 0.705 & Reliabel \\
\hline \multicolumn{2}{|c|}{ Sumber: hasil penelitian (Mei, 2019) } \\
diolah
\end{tabular}

Berdasarkan Tabel 1.8. Tersebut dapat disimpulkan bahwa semua item pertanyaan variabel penelitian sudah reliabel, karena $\mathrm{r}_{\text {alpha }}>0,60$. Maka seluruh variabel dalam penelitian ini memiliki kehandalan dan dapat digunakan untuk melanjutkan penelitian.

\section{Uji Asumsi Klasik}

Uji asumsi klasik digunakan untuk mendapatkan hasil regresi yang valid, terdapar 3 uji asumsi klasik pada penelitian ini yaitu uji normalitas, uji multikolinearitas, dan uji heterokedastisitas.

\section{Uji Normalitas}

Pengujian normalitas disini mengunakan one sample kolmogorovsmimov test dan grafik P-Plot yang digunakan untuk mengetahui apakah dalam model regresi panel variabelvariabelnya berdistribusi normal atau tidak. Model regresi yang baik adalah memiliki distribusi data normal atau mendekati normal (Ansofino, 2016:22). Data dikatakan berdistribusi normal apabila probabilitas nilai signifikan lebih besar dari 0,05. Berikut hasil pengujian normalitas dilakukan dengan melihat nilai asym.Sig. Pada hasil uji normalitas dengan menggunakan one sample kolmogorovsmirnov test dengan jumlah responden sebanyak 100 nasabah:

Tabel 1.9

One-Sampel Kolmogorov-Smirnov Test

\begin{tabular}{|l|c|}
\hline & $\begin{array}{c}\text { Unstandardized } \\
\text { Residual }\end{array}$ \\
\hline $\mathrm{N}$ & 100 \\
\hline $\begin{array}{l}\text { Kolmogorov- } \\
\text { Smirnov Z }\end{array}$ & 0,814 \\
\hline $\begin{array}{l}\text { Asymp. Sig. } \\
\text { (2-tailed) }\end{array}$ & 0,521 \\
\hline
\end{tabular}

Sumber: hasil penelitian (Mei, 2019) diolah

Berdasarkan Tabel 1.9. menunjukkan Asymp. Sig (2-tailed) adalah 0,521 yang berarti tingkat signifikansi $>0,05$. Jadi dapat disimpulkan bahwa data yang telah beredar sudah berdistribusi secara normal. Pada hasil uji normalitas dengan menggunakan grafik P-Plot 
dengan jumlah responden sebanyak 100 nasabah.

\section{Gambar 1.1 P-Plot}

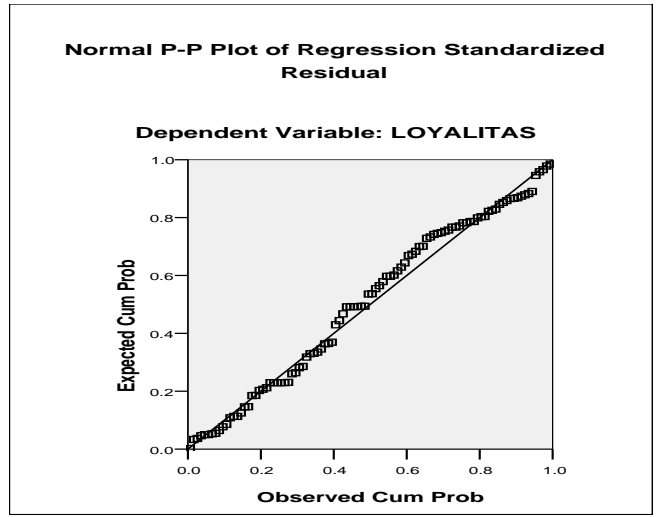

Sumber: Hasil penelitian (Mei, 2019) diolah

Berdasarkan tabel normalitas data seperti yang terlihat pada Gambar 1.1 dapat dijelaskan bahwa data setiap variabel dalam penelitian ini sudah terdistribusi dengan normal, karena jika dilihat dari grafik residual membentuk garis diagonal. Jadi uji normalitas pada penelitian ini terpenuhi atau terdistribusi secara normal.

\section{Uji Heteroskedastisitas}

Uji heteroskedastisitas dilakukan untuk menguji sebuah model regresi linier apakah terjadi ketidaksamaan varian dari residual pengamatan ke pengamatan yang lain. Model regresi yang baik apabila tidak terjadi heterokedastisitas dengan melihat pada grafik scatter plot.

\section{Gambar 1.2 Scatterplot}

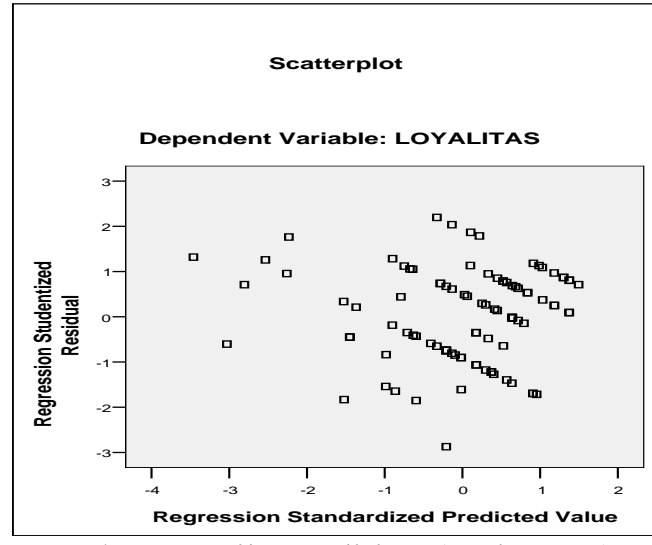

Sumber: Hasil penelitian (Mei, 2019) diolah

Berdasarkan Gambar 1.2 tersebut menunjukkan bahwa titik-titik yang dihasilkan menyebar secara acak dan tidak membentuk suatu pola atau trend garis tertentu. Maka, hasil pengujian ini menunjukkan bahwa model regresi ini bebas dari masalah heteroskedastisitas karena titik-titik yang tersebar tidak membentuk sebuah garis.

\section{Uji Multikolinearitas}

Cara mendeteksi multikolinearitas adalah dengan melihat hasil nilai toleransi (tolerance) dan V ariance Inflation Factor (VIF) pada tabel Coeffsien. Jika nilai tolerance $>$ 0,1 dan nilai VIF $<10$ maka dapat dikatakan tidak ada multikolinearitas antar variabel independen. Hasil uji multikolinearitas dapat dilihat pada tabel berikut:

Tabel 1.10

\section{Multikolinearitas Variabel Independen Penelitian}

\begin{tabular}{|c|c|c|}
\hline \multirow{2}{*}{ Model } & \multicolumn{2}{|c|}{ Collinearity Statistic } \\
\cline { 2 - 3 } & Tolerance & VIF \\
\hline
\end{tabular}


$116 \sim$ Pengaruh Religiusitas, Kualitas Pelayanan,

Kualitas Produk Terhadap Loyalitas Nasabah

Tabungan Pada PT. Bank Aceh Syariah

Kantor Cabang Pembantu Darussalam

\begin{tabular}{|l|c|c|}
\hline Religiusitas & 0,847 & 1,180 \\
\hline $\begin{array}{l}\text { Kualitas } \\
\text { Pelayanan }\end{array}$ & 0,885 & 1,130 \\
\hline $\begin{array}{l}\text { Kualitas } \\
\text { Produk }\end{array}$ & 0,776 & 1,288 \\
\hline
\end{tabular}

Sumber:Hasil Penelitian (Mei, 2019) diolah

Berdasarkan Tabel 1.10 tersebut dapat dilihat bahwa nilai VIF yang besarnya kurang dari 10 dan nilai toleransi jauh melebihi angka 0,01 sehingga tidak terjadi penyimpangan multikolinearitas.

\section{Hasil Analisis Regresi Linier Berganda}

Hasil regresi penelitian ini terdapat variabel dependen yaitu Loyalitas Nasabah (L). Sedangkan variabel independennya adalah Religiusitas (R), Kualitas Pelayanan (Kp), dan Kualitas Produk (P). Untuk melihat hasil analisis regresi linear berganda berikut disajikan dalam tabel di bawah ini:

Tabel 1.11

Hasil Uji Analisis Linier Berganda

\begin{tabular}{|c|c|c|c|c|}
\hline \multirow{2}{*}{ Model } & \multicolumn{2}{|c|}{ UnstandardizedCoefficients } & \multirow{2}{*}{$\mathbf{T}$} & \multirow{2}{*}{ Sig } \\
\hline & $\mathbf{B}$ & Std. Error & & \\
\hline (Constant) & 0,211 & 0,526 & 0,402 & 0,688 \\
\hline $\mathrm{R}$ & 0,388 & 0,107 & 3,645 & 0,000 \\
\hline $\mathrm{Kp}$ & 0,280 & 0,086 & 3,271 & 0,001 \\
\hline $\mathrm{P}$ & 0,277 & 0,088 & 3,169 & 0,002 \\
\hline
\end{tabular}

Sumber: Hasil Penelitian (Mei,2019) diolah

Berdasarkan hasil data pada tabel 1.11 diatas dapat diperoleh persamaan linier berganda sebagai berikut :

$$
\mathrm{L}=0.211+0.388(\mathrm{R})+0.280
$$

$(\mathrm{Kp})+0.277(\mathrm{P})$

Berdasarkan persamaan tersebut diatas, dapat disimpulkan bahwa :
a. Konstanta
(a) $=0,211$, mempunyai arti jika variable bebas tersebut sama dengan 0 , maka variable Loyaitas Nasabah akan tetap sebesar 0,211.
b. Nilai koefesien regresi variabel Religiusitas $(\mathrm{R}) \quad=\quad 0,388$.

Mempunyai arti memiliki hubungan yang positif. Jadi, jika kenaikan variable Religiusitas (R)sebesar $1 \%$, maka akan terjadi kenaikan sebesar 38,8\% terhadap variable Loyaitas Nasabah (L)

c. Nilai koefesien Kualitas Pelayanan $(\mathrm{Kp})=0,280$. Mempunyai arti memiliki hubungan yang positif. Jadi, jika kenaikan Kualitas Pelayanan (Kp) sebesar $1 \%$, maka akan terjadi kenaikan sebesar 28\% terhadap variable Loyaitas Nasabah (L)

d. Nilai koefesien Kualitas Produk $(\mathrm{P})=0,277$. Mempunyai arti 
bahwa memiliki hubungan yang positif. Jadi, jika kenaikan kualitas produk (P) sebesar $1 \%$, maka akan terjadi kenaikan sebesar $27,7 \%$ terhadap variable Loyaitas Nasabah (L)

\section{Hasil Uji Hipotesis secara Parsial}

(t)

Berikut ini adalah hasil uji-t yang dilakukan untuk mengetahui apakah ada pengaruh secara persial pada variabel bebas berpengaruh signifikan terhadap variabel terikat.

Tabel 1.12

Hasil Uji-t

\begin{tabular}{|c|c|c|}
\hline Model & T & Sig \\
\hline Religiusitas & 3,645 & 0,000 \\
\hline KualitasPelayanan & 3,271 & 0,001 \\
\hline Kualitas Produk & 3,169 & 0,002 \\
\hline
\end{tabular}

Sumber: Hasil Penelitian (Mei, 2019) diolah

Berdasarkan tabel 1.12. diatas, dapat diketahui bahwa :

a. Hipotesis $\mathrm{H}_{1}$ diterima, karena $t_{\text {hitung }}>t_{\text {tabel }}(3.645>1.660)$ atau signifikan 0.00. Jadi, dapat disimpulkan bahwa variable religiusitas (R) berpengaruh positif dan signifikan terhadap variable loyalitas nasabah (L). Penelitian ini mendukung atau sesuai dengan penelitian sebelumnya yang dilakukan oleh Aulisia (2017). Namun berbeda halnya dengan penelitian Bakri (2018) menunjukkan bahwa tidak terdapat pengaruh antara nilai-nilai Religius seperti keadilan, kesederajatan dan kejujuran terhadap loyalitas nasabah baik itu secara parsial maupun bersama-sama.

b. Hipotesis $\mathrm{H}_{2}$ diterima, karena $t_{\text {hitung }}>t_{\text {tabel }}(3,271>1.660)$ dan tingkat signifikan 0.01. Jadi, dapat disimpulkan bahwa variable kualitas pelayanan $(\mathrm{Kp})$ berpengaruh positif dan signifikan terhadap variable loyalitas nasabah (L). Penelitian ini mendukung atau sesuai dengan penelitian sebelumnya yang dilakukan oleh Wijayanto (2015).

c. Hipotesis $\mathrm{H}_{3}$ diterima, karena $\mathrm{t}_{\text {hitung }}>\mathrm{t}_{\text {tabel }}(3.169>1.660)$ dan tingkat signifikan 0.002. Jadi dapat disimpulkan bahwa variable kualitas produk (P) berpengaruh positif dan signifikan terhadap variable loyalitas nasabah (L). Penelitian ini mendukung atau sesuai dengan penelitian sebelumnya yang dilakukan oleh Ismail (2014).

\section{Hasil Uji Hipotesis secara Simultan (F) \\ Berikut ini adalah hasil uji-F yang dilakukan untuk mengetahui}


$118 \sim$ Pengaruh Religiusitas, Kualitas Pelayanan,

Kualitas Produk Terhadap Loyalitas Nasabah

Tabungan Pada PT. Bank Aceh Syariah

Kantor Cabang Pembantu Darussalam

apakah pengaruh secara simultan pada variabel bebas berpengaruh positif dan signifikansi terhadap variabel terikat.

Tabel 1.13

\section{Hasil Uji-F}

\begin{tabular}{|c|c|c|}
\hline Model & F & Sig \\
\hline Regression & 21,655 & 0,000 \\
\hline \multicolumn{2}{|c|}{ Sumber: Hasil Penelitian (Mei, } \\
2019) diolah
\end{tabular}

Berdasarkan tabel 1.13. diatas, dapat diketahui bahwa nilai $F_{\text {hitung }}$ sebesar 21,655, dengan tingkat signifikansi p-value sebesar 0,00 atau < 0,05 sedangkan $F_{\text {tabel }}$ 3.09. Jadi dapat disimpulkan bahwa $\mathrm{F}_{\text {hitung }}>\mathrm{F}_{\text {tabel }}$ $(21,655>3.09)$, berarti adanya pengaruh signifikan antara variabel Religiusitas, Kualitas Pelayanan, Kualitas Produk, secara bersama-sama (simultan) terhadap Loyalitas Nasabah. Penelitian ini mendukung atau sesuai dengan penelitian sebelumnya yang dilakukan oleh Efriandy (2013).

\section{KESIMPULAN DAN SARAN}

Kesimpulan

Berdasarkan hasil penelitian bahwa variabel Religiusitas (R), Kualitas Pelayanan(Kp), dan kualitas produk (P) secara bersama-sama berpengaruh signifikan terhadap Loyalitas Nasabah (L). Di mana melihat probabilitasnya (Sig) yang lebih kecil dari taraf signifikan (0.000) maka dapat disimpulkan bahwa bentuk persamaan tersebut diterima dan berpengaruh signifikan. Variabel
Religiusitas (R) berpengaruh signifikan terhadap Loyalitas Nasabah (L), karena $t_{\text {hitung }}>t_{\text {tabel }}(3,645>1.660)$. Variabel Kualitas Pelayanan $(\mathrm{Kp})$, berpengaruh signifikan Loyalitas Nasabah (L), yaitu sebesar 0.001. Hal tersebut dapat dibuktikan dengan $\mathrm{t}_{\text {hitung }}$ $>t_{\text {tabel }}(3,169>1.660)$. Variabel Kualitas Produk (P) berpengaruh signifikan terhadap terhadap Loyalitas Nasabah (L), yaitu sebesar 0.002. Hal tersebut dapat dibuktikan dengan $t_{\text {hitung }}$ $>\mathrm{t}_{\text {tabel }}(3,271>1.660)$.

Daftar Pustaka

Aliansyah, Teuku., dkk. 2012. Pengaruh Dimensi Kualitas Pelayanan Terhadap Kepuasan Nasabah Bank Aceh Syariah Cabang Banda Aceh, Jurnal Manajemen Pasca SarjanaUniversitas Syiah Kuala, Vol.1 No.1

Amir, Machmud. 2010. Bank Syariah kebijakan dan Studi Empiris di Indonesia Jakarta: Erlangga.

Ancok, D. \& Suroso, F. N. 2008. Psikologi Islami Solusi Islam Atas Problem-Problem Psikologi. Yogayakarta: Pustaka Pelajar.

Ansofino, dkk. 2016. Buku Ajar Ekonometrika. Yogyakarta: Deepublish.

Arikunto, Suharsimi. 2010. Prosedur penelition suatu pendekatan praktik, Jakarta: Rineka cipta

Assael, Consumer Bebavior and Marketing Action. 2002. edisi3 Boston Massachusset,AS: Kent Published Company,2002 
Bank Aceh. 2019. Bank Aceb SyariabRaib "Top Bumd 2019". Melaluihttp://www.bankaceh. co.id.Diaksespadatanggal 15 februari 2019.

Enge, James,l et al, Prilaku Konsumen Jilid 2 , 1994. Jakarta:Binarupa Aksara.1994

Farlian, Talbani dan nuraidar. 2017. Meretas Reaksi Jalan Panjang Bank Aceh Konversi Syariah. Jurnal Perspektif Ekonomi Darussalam. Volume 3 Nomor 1, Maret

Fuad, Nashori dan Rachmy Diana Mucharam. 2002.

Mengembangkan Kreativitas dalam Perspektif Psikologi Islam.Yogyakarta : Menara Kudus

Hasan, Ali. 2010. Marketing Bank Syariah. Bogor: Ghalia Indonesia

Hidayat, Rachmat. 2009. Pengaruh Kualitas Layanan, Kualitas Produk Dan Nilai Nasabah Terhadap Kepuasan Dan Loyalitas Nasabah Bank Mandiri.Jurnal Manajemen Dan Kewirausabaan. Vol.11, No. 1, Maret: 59-72.

Jalaludin, Rahmat. 2003. Psikologi Agama. Jakarta: Raja Grafindo Persada.

Kartajaya , Hermawan, 2007 Boosting Loyalty Marketing Performance,Jakarta: Markplus Inc dan Bandung: Mizan Pustaka
Kotler, Philip \& Gary Amstrong. 2002. Manajemen Pemasaran di Indonesia : Analisis, Perencanaan, Implementasidan Pengendalian, Jakarta : Salemba Empat,

Lupiyoadi, Rambat. 2001. Manajemen Pemasaran Jasa. Jakarta: Salemba empat.

Lupiyoadi, Rambat 2009. Manajemen Pemasaran Jasa, Edisi II. Jakarta: Salemba Empat.

Nuraini. 2009. Analisis Pengaruh Kualitas Produk, Kualitas Pelayanan, Desain Produk, Harga Dan Kepercayaan Terhadap Loyalitas Pelanggan. Skripsi

Saravanakumar, Effect of service quality on customer loyalty: Emperical Devidance from cooperative bank. Int.J.Bus. Adm Res, Rev. 2, 87-94

Suhardiyanto. 2001. Pendidikan Religiusitas, Jogjakarta: Kanisius

Tjiptono, Fandy. 1997. Prinsip-prinsip Total Quality Service. Yogyakarta: Andi Offset.

Tjiptono, Fandy. 2002. Strategi Pemasaran. Yogyakarta: Andi.

Umar. 2001, Rumus Slovin dalam Penentuan Sampel. Jakarta: Kelompok Gramedia

Wahyu, S. 2015. Analisis Pengaruh Komitmen Pelanggan, Kepercayaan dan Kepuasan Nasabah terhdap Loyalitas Nasabah pada PT Bank Negara Indonesia Kantor Wilayah Semarang. Skripsi. 
$120 \sim$ Pengaruh Religiusitas, Kualitas Pelayanan,

Kualitas Produk Terhadap Loyalitas Nasabah

Tabungan Pada PT. Bank Aceh Syariah

Kantor Cabang Pembantu Darussalam

Wijaya, Toni. 2011. Manajemen Kualitas

Jasa. Jakarta barat: PT. Indeks. 